\title{
BACILLUS THURINGIENSIS MONOGENIC STRAINS: SCREENING AND INTERACTIONS WITH INSECTICIDES USED AGAINST RICE PESTS
}

\author{
Laura M.N. Pinto ${ }^{1 *}$, Natália C. Dörr ${ }^{1}$, Ana Paula A. Ribeiro ${ }^{1}$, Silvia M. de Salles ${ }^{1}$, Jaime V. de Oliveira ${ }^{2}$, Valmir G. \\ Menezes $^{2}$, Lidia M. Fiuza ${ }^{1,2}$
}

${ }^{1}$ Universidade do Vale do Rio dos Sinos, Programa de Pós-Graduação em Biologia, Laboratório de Microbiologia e Toxicologia, São Leopoldo, RS, Brasil; ${ }^{2}$ Instituto Rio Grandense do Arroz, Estação Experimental do Arroz, Cachoerinha, RS, Brasil.

Submitted: January 21, 2011; Returned to authors for corrections: July 04, 2011; Approved: January 16, 2012.

\begin{abstract}
The screening of Bacillus thuringiensis (Bt) Cry proteins with high potential to control insect pests has been the goal of numerous research groups. In this study, we evaluated six monogenic Bt strains (Bt dendrolimus HD-37, Bt kurstaki HD-1, Bt kurstaki HD-73, Bt thuringiensis 4412, Bt kurstaki NRD-12 and Bt entomocidus 60.5, which codify the crylAa, crylAb, crylAc, crylBa, crylC, cry $2 A$ genes respectively) as potential insecticides for the most important insect pests of irrigated rice: Spodoptera frugiperda, Diatraea saccharalis, Oryzophagus oryzae, Oebalus poecilus and Tibraca limbativentris. We also analyzed their compatibility with chemical insecticides (thiamethoxam, labdacyhalothrin, malathion and fipronil), which are extensively used in rice crops. The bioassay results showed that Bt thuringiensis 4412 and Bt entomocidus 60.5 were the most toxic for the lepidopterans, with a $93 \%$ and $82 \%$ mortality rate for $S$. frugiperda and D. saccharalis, respectively. For O. oryzae, the Bt kurstaki NRD-12 (64\%) and Bt dendrolimus HD-37 (62\%) strains were the most toxic. The Bt dendrolimus HD-37 strain also caused high mortality $(82 \%)$ to $O$. poecilus, however the strains assessed to $T$. limbativentris caused a maximum rate of $5 \%$. The assays for the $B t$ strains interaction with insecticides revealed the compatibility of the six strains with the four insecticides tested. The results from this study showed the high potential of $c r y 1 A a$ and $c r y l B a$ genes for genetic engineering of rice plants or the strains to biopesticide formulations.
\end{abstract}

Key words: Bacillus thuringiensis, Cry proteins, Insects.

\section{INTRODUCTION}

Bacillus thuringiensis is an endospore-forming Grampositive bacterium of economic importance due to its capacity of synthesizing bioinsecticidal proteins. Such proteins have been characterized and assessed to control insect species. They are codified by cry genes localized in plasmids, and one strain can host more than one cry gene, thus making it possible to synthesize different toxins by the same bacterium $(12,22)$ and evidencing its large potential of insecticidal activity.

\footnotetext{
*Corresponding Author. Mailing address: UNISINOS, Programa de Pós-Graduação em Biologia, Laboratório de Microbiologia e Toxicologia. CEP 93001-970, São Leopoldo, RS/Brasil.; E-mail: lauramnp@yahoo.com.br
} 
The activity spectrum of a Cry protein is defined as the range of species or taxa that it affects. Cryl genes are most frequent in nature, representing over $43 \%$ of the reported cry genes. This class synthesizes proteins toxic mainly to the Lepidoptera order, while cry 2 genes are toxic both to the Lepidoptera and Diptera orders $(8,23)$. Cross-order activity has been shown in 15 of the 87 pesticide crystal protein families, and most toxins were assessed for 10 species or less. In addition, the species and toxins analyzed are not equally distributed across protein families and taxa (16).

Studies about the B. thuringiensis toxicity for hemipterans are rare, particularly for $O$. poecilus and $T$. limbativentris, as well as for the coleopteran $O$. oryzae. This is due to the fact that rearing protocol for these insects in laboratory has not been completely established yet, reducing the number and period of replicates to the irrigated rice cultivation season.

Rice is the basic food for over $50 \%$ of the world's population, but rice crops are losing almost $28 \%$ of productivity due to the incidence of insect pests (28). In addition to the environmental issues, the use of chemical products to control insect pests in irrigated rice field areas represents high maintenance costs. Thus, the application of commercial products based on $B$. thuringiensis and the incorporation of its cry genes in plants with agronomic interest $(2,12,45)$ represents a new strategy to control these insects in different agroecosystems, without causing such great environmental harm.

In order to use an entomopathogen associated with chemical insecticides, it is necessary to assess these products' action against the microorganism, and then to determine their compatibility. Batista Filho (7) assessed the compatibility of entomopathogenic microorganisms with thiamethoxam and other insecticides and identified the compatibility between thiamethoxam and the growth of $B$. thuringiensis.

According to the South Brazilian Rice Technical Committee (CTAR) from South Brazilian Irrigated Rice Society (SOSBAI), some chemical insecticides such as thiamethoxam, labdacyhalothrin, malathion and fipronil are used in irrigated rice crops, in addition to biological insecticides such as the commercial formulation with $B$. thuringiensis kurstaki HD-1 strain.

Regarding the efficiency of using genetically modified plants with Bacillus thuringiensis cry genes, Fugimoto et al. (17) showed for the first time rice plants resistant to insects through the insertion of $c r y l A b$ truncated gene with biological activity specific to lepidopterans.

Thenceforth, other cry genes have been introduced into different plants (31) to control target insects of agricultural relevance. These researches evidence that rice varieties transformed with $B$. thuringiensis cry genes can have high potential in reducing the damage caused by insect pests, mainly lepidopterans, as shown in cotton, corn, potato, among other crops.

In this context, the objective of this research was to screen, through in vivo assays using target insects, six monogenic B. thuringiensis strains, codifying Cry1 and Cry2 proteins with high potential to be used in genetic engineering and Integrated Pest Management. The interaction between the same $B$. thuringiensis strains and four chemical insecticides was also analyzed using in vitro assays.

\section{MATERIALS AND METHODS}

\section{Insects}

The insects Oryzophagus oryzae, Tibraca limbativentris and Oebalus poecilus were collected in their natural occurrence season in rice crop areas, and the individuals were maintained at UNISINOS insect room with controlled temperature and humidity $\left(25 \pm 2^{\circ} \mathrm{C}, 80 \%\right.$ of relative humidity, and a photophase of 12 hours). The rearing of Spodoptera frugiperda and Diatraea saccharalis was conducted at UNISINOS using the same conditions described above.

\section{Bacillus thuringiensis strains}

The monogenic strains $B$. thuringiensis dendrolimus HD- 
37, B. thuringiensis kurstaki HD-1, B. thuringiensis kurstaki HD-73, B. thuringiensis thuringiensis 4412, B. thuringiensis entomocidus 60.5, and B. thuringiensis kurstaki NRD-12, which harbored the crylAa, crylAb, crylAc, crylBa, crylC, cry $2 A$ genes, respectively, were provided by the International Entomopathogenic Bacillus Center from Pasteur Institut (Paris).

\section{Cry proteins characterization}

The protein composition of the six B. thuringiensis strains was analyzed using a 10\% Sodium Dodecyl Sulphate Polyacrylamide Gel (SDS-PAGE). Each strain was grown at $30^{\circ} \mathrm{C}$ for 48 hours in Glucosed Usual Medium (MUG) (13), until the autolysis was completed. The spore-crystal complex was prepared using $62 \mathrm{mmol} \mathrm{L}^{-1}$ Tris- $\mathrm{HCl} \mathrm{pH}$ 6.8; 4\% SDS; $20 \%$ glycerol; $5 \% \beta$-mercaptoethanol and $0.02 \%$ bromophenol blue, heated at $100^{\circ} \mathrm{C}$ for ten minutes and centrifuged at a spin, and $15 \mu \mathrm{L}$ were loaded in each well. The SDS-PAGE electrophoresis was developed according to the method described by Laemmili (21).

\section{Chemical Insecticides}

In this study we analyzed the interaction of the six Bacillus thuringiensis strains described before with the insecticides recommended by the South Brazilian Rice Technical Committee (CTAR) and the South Brazilian Irrigated Rice Society (SOSBAI) (37) for the control of insect pests in the irrigated rice areas of Rio Grande do Sul (Table 1).

Table 1. Chemical insecticides used in interaction assays with Bacillus thuringiensis (37).

\begin{tabular}{lll}
\hline Active ingredient (a. i.*) & Formulation** & Recommended dose (g or mL/ha) \\
\hline Thiamethoxam & WG 250 & $150 \mathrm{~g}$ \\
Labdacyhalothrin & CS 50 & $150 \mathrm{~mL}$ \\
Malathion & CE 500 & $1500 \mathrm{~mL}$ \\
Fipronil & 250 & $150 \mathrm{~mL}$ \\
\hline *active ingredient; **grams of a.i./kg or L. &
\end{tabular}

\section{In vivo B. thuringiensis assays}

The in vivo assays using target insects were carried out in Biological Oxygen Demand (BOD) chambers at $25 \pm 2{ }^{\circ} \mathrm{C}, 80 \%$ R.H. and a photophase of 12 hours. The B. thuringiensis strains were grown in MUG, and the bacterial suspensions were centrifuged $7.000 \mathrm{~g}$ for 15 minutes. The supernatant was discarded and the final pellet diluted in autoclaved distilled water. The concentrations were determined by placing $0.1 \mathrm{~mL}$ of each suspension in a Neubauer-counting chamber and counted using optical microscopy under 400 magnification.

Spodoptera frugiperda and Diatraea saccharalis: bacterial suspensions in a concentration of $1 \times 10^{10}$ cells $/ \mathrm{mL}$ were applied on the surface of the artificial diet $(32,39)$ previously placed on $30 \mathrm{~mm}$-diameter plastic dishes, where second instar larvae were placed individually. Twenty larvae were evaluated for each strain, with three replicates to $S$. frugiperda and to D. saccharalis, totalizing 420 and 270 evaluated insects respectively.

Oryzophagus oryzae: The bacterial suspensions in a concentration of $1 \times 10^{10}$ cells $/ \mathrm{mL}$ were placed in assay tubes containing a rice plant and $10 \mathrm{~mL}$ of distilled water, and each tube was infested with five $O$. oryzae larvae. Twenty third and fourth instar of $O$. oryzae larvae were used in each treatment, with four replicates, totalizing 560 evaluated insects.

Tibraca limbativentris: $250 \mu \mathrm{L}$ of bacterial suspensions in a concentration of $1 \times 10^{10}$ cells $/ \mathrm{mL}$ were injected in each rice plant with a syringe. The plant roots were involved in sterilized wet cotton to keep them hydrated. The plants were then placed 
individually in four plastic flasks with five adult stink bugs, with 20 insects per treatment. The top of the flask was then covered with a thin tissue. Two replicates were performed for each treatment, totalizing 280 evaluated insects.

Oebalus poecilus: $100 \mu \mathrm{L}$ of bacterial suspensions in a concentration of $1 \times 10^{10}$ cells $/ \mathrm{mL}$ were applied on the surface of five hygienized rice grains previously placed in Petri dishes. After the liquid suspension was absorbed by the grains, they were infested with five insects per Petri dish. The bioassays were constituted of 20 insects per treatment, and two replicates, totalizing 280 evaluated insects.

In the control treatments of all bioassays the strains were substituted by sterilized distilled water. The mortalities were evaluated until the seventh day after the treatments were initiated. The mortality data obtained was corrected using Abbott's formula (1). The data from the bioassays with $S$. frugiperda and $O$. oryzae was compared by analysis of variance (ANOVA) and the means of significant effect were separated using Tukey's test at P > 0.05 level, using the SPSS Statistical Software (39).

\section{In vitro B. thuringiensis and insecticides interactions}

The B. thuringiensis strains were grown in MUG at 180 $\mathrm{rpm}$ and $30^{\circ} \mathrm{C}$ for 48 hours. After this, the bacterial suspensions were centrifuged twice at $7.000 \mathrm{~g}$ for 20 minutes and the supernatant was discarded. The pellet was diluted in sterilized distilled water and the bacterial concentrations were standardized to $7 \times 10^{9}$ cells $/ \mathrm{mL}$. The insecticides were diluted with sterilized distilled water according to the recommended doses (Table 2) and applied on $3 \mathrm{~cm}^{2}$ sterilized filter paper discs, which were placed in $9 \mathrm{~cm}$ diameter Petri dishes. Bacteria were inoculated in four Petri dishes with Nutrient Agar (NA), each dish with the corresponding strain, followed by the placement of the paper disc with the evaluated insecticide in the center of the dish. In the control treatment, a filter paper disc with sterilized distilled water replaced the insecticide. For each tested insecticide, three replicates were developed, totalizing 12 dishes per treatment. The data was analyzed on the $4^{\text {th }}$ and $7^{\text {th }}$ day after the treatment application. Each NA Petri dish was analyzed for the absence or presence and the size $(\mathrm{mm})$ of the bacterial growth inhibition halo.

\section{RESULTS AND DISCUSSION}

\section{Bacillus thuringiensis toxicity}

The In vivo effects showed that the analyzed insects have different susceptibility levels to the six $B$. thuringiensis evaluated strains. The strains that showed wider action spectrum were $B$. thuringiensis dendrolimus HD37, B. thuringiensis thuringiensis 4412, and B. thuringiensis entomocidus 60.5, which synthesize Cry1Aa, Cry1Ba and Cry1C proteins respectively (Figure 1). These three strains caused over $10 \%$ of corrected mortality to the five analyzed insect species, except to $T$. limbativentris, which was not susceptible to this bacterium (Table 2). The B. thuringiensis kurstaki HD73 strain had the smallest action spectrum, although its highest mortality indexes were against $O$. oryzae and $O$. poecilus, with $54 \%$ and $20.5 \%$, respectively.

Table 2. Bacillus thuringiensis (Bt) strains pathogenicity to insect pests of irrigated rice.

\begin{tabular}{|c|c|c|c|c|c|c|}
\hline \multirow{2}{*}{\multicolumn{2}{|c|}{$\begin{array}{l}\text { Bt strains patogenicity }{ }^{1} \text { and Cry } \\
\text { proteins }\end{array}$}} & \multicolumn{5}{|c|}{ Insects } \\
\hline & & $\begin{array}{c}\text { Oryzophagus } \\
\text { oryzae }\end{array}$ & $\begin{array}{l}\text { Spodoptera } \\
\text { frugiperda }\end{array}$ & $\begin{array}{c}\text { Diatraea } \\
\text { saccharalis }\end{array}$ & $\begin{array}{l}\text { Oebalus } \\
\text { poecilus }\end{array}$ & $\begin{array}{c}\text { Tibraca } \\
\text { limbativentris }\end{array}$ \\
\hline Bt dendrolimus HD37 & - Cry1Aa & + & + & + & + & - \\
\hline Bt kurstaki HD1 & - Cry1Ab & + & - & + & + & - \\
\hline Bt kurstaki HD73 & - Cry1Ac & + & - & - & + & - \\
\hline Bt thuringiensis 4412 & - Cry1Ba & + & + & + & + & - \\
\hline Bt entomocidus 60.5 & - Cry1C & + & + & + & + & - \\
\hline Bt kurstaki NRD-12 & Cry2A & + & - & + & + & - \\
\hline
\end{tabular}

${ }^{1}$ corrected mortality: higher (+) and lower (-) than $10 \%$. 


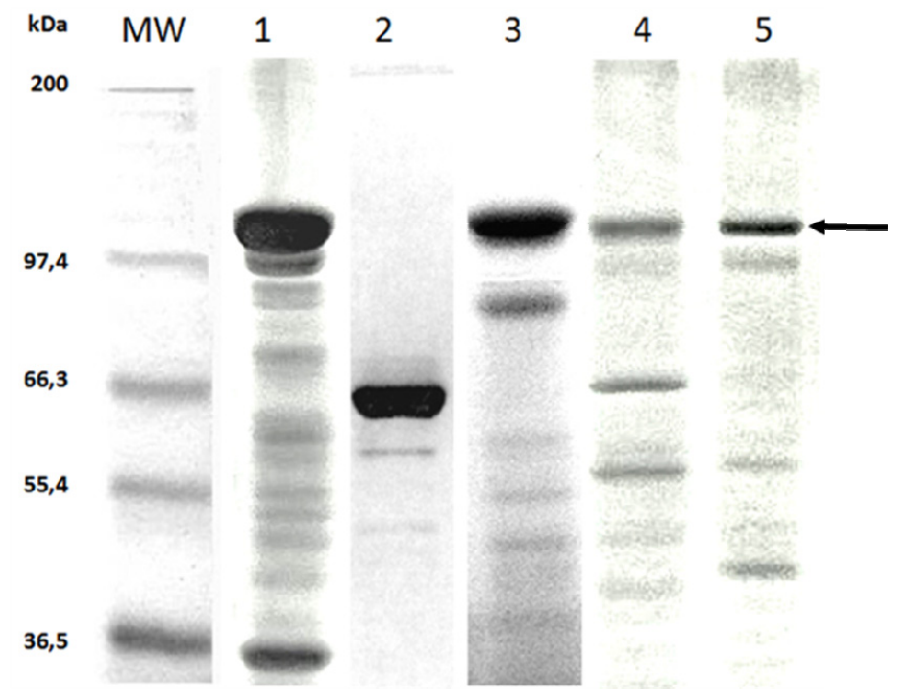

Figure 1. Bacillus thuringiensis $(B t)$ strains analyzed in SDSPAGE 10\%. Lanes: (1) Bt dendrolimus HD-37; (2) Bt kurstaki HD-1 (trypsin activated toxin); (3) Bt kurstaki HD-73; (4) Bt thuringiensis 4412; and (5) Bt entomocidus 60.5; (MW) Molecular Weight, with sizes in $\mathrm{kDa}$ indicated on left (Mark12 $^{\mathrm{TM}}$ Unstained Std., Invitrogen ${ }^{\mathrm{R}}$ ). Protein bands of expected size, around $130 \mathrm{kDa}$, are indicated by arrow.

Because of the natural occurrence of these insects during the development of rice crops (29), the results obtained suggest the use of plants or products based on Cry1Aa, Cry1C and Cry2A B. thuringiensis proteins.

The strain B. thuringiensis entomocidus 60.5, which caused higher toxicity to D. saccharalis $(82.5 \%)$, is characterized by the presence of the crylC gene, and these results corroborate the ones obtained by Rosas-García et al. (32). They identified the crylC gene in two B. thuringiensis strains also highly toxic to D. saccharalis. Gitahy et al. (18) assessed the insecticidal potential of five Brazilian $B$. thuringiensis strains and only one presented high toxicity, causing $100 \%$ mortality of the analyzed insects, but the others caused less than $3 \%$. These authors mentioned that the strain with higher toxicity, called S76, revealed through the Polymerase Chain Reaction (PCR) the presence of crylAa, $c r y 1 A b, c r y 1 A c, c r y 2 A a$ and $c r y 2 A b$ genes. However, the authors reported that when the proteins codified by these genes were evaluated separately, they did not cause high mortality to D. saccharalis.

Bohorova et al. (8) transformed a corn variety introducing a codon optimized $c r y l B$ gene, and $25 \%$ of transformed corn plants showed resistance to $D$. saccharalis. These results also make it evident that the Cry1Ba protein causes mortality to $D$. saccharalis, and modified plants with crylBa genes can represent an efficient alternative in the control of the insect population.

Regarding the hemipterans, even though we observed low mortality only with $T$. limbativentris, these results are important since the literature consulted lacks data regarding the action of $B$. thuringiensis against this insect. Until now, the action of $B$. thuringiensis had been poorly studied with hemipterans insects, and the few published works $(43,44)$ revealed low or no toxic activity for the analyzed strains, and the main results for this insect order refer to the $B t$-plants action against natural enemy populations, not to insect pests. For the studied hemipterans, the strain that caused higher mortality in T. limbativentris was B. thuringiensis dendrolimus HD37 (5.2\%), followed by B. thuringiensis kurstaki HD1 $(3.5 \%)$. The others strains were not pathogenic to the rice stink bug. Six strains were analyzed against $O$. poecilus adults, and three of them caused over $40 \%$ of mortality, while the strains B. thuringiensis kurstaki HD1 and B. thuringiensis dendrolimus HD37 caused around 50\% of mortality, thus representing alternatives to the grain stink bug control.

$S$. frugiperda and $O$. oryzae larvae are currently considered the major irrigated rice pests in the South Region of Brazil, so further assays were developed to determine how toxic the strains are against the insect pests.

To the coleopteran $O$. oryzae, all of the assessed $B$. thuringiensis strains showed control potential, causing a minimum of $50 \%$ of corrected mortality. The strain that caused the highest mortality rate was B. thuringiensis kurstaki NRD- 
12 (Cry2A), with $64.48 \%$ of corrected mortality, followed by B. thuringiensis dendrolimus HD37 (Cry1Aa), with $61.98 \%$ (Table 3). Martins et al. (25) analyzed 215 B. thuringiensis strains against the coleopteran Anthonomus grandis and found five strains that caused over $50 \%$ of mortality rate. Out of these five, the most toxic strain contained the $\operatorname{cry} l B$ gene and two cry2 genes. Until then, works with Cry2 protein against coleopterans had still not been reported. Although Cryl proteins have originally been related in regards to their toxicity for lepidopterans, many studies have already reported their toxicity for coleopterans $(10,23,25,26,30)$. These results evidence the toxic potential of Cry1 and Cry 2 proteins against coleopterans, which until then was essentially associated to Cry3 and Cry9 proteins $(11,19)$.

In this work the proteins that caused high mortality in $S$. frugiperda were Cry1Ba (93.1\%) and Cry1C (86.0\%) (Table 3). Because of the economic importance of $S$. frugiperda, which, in addition to infesting rice was also found to be associated with corn, peanut, cotton, soybean, alfalfa and forage grasses, many research groups make prospection of $B$. thuringiensis strains with insecticidal activity against this insect (33). The most recent publications have analyzed new $B$. thuringiensis strains active against $S$. frugiperda $(4,14,35,41)$, which contain different cry genes in their genomes, thus representing new strain alternatives to commercial formulations with this entomopathogen.

From the analysis of the laboratory in vivo toxicity results, the strains $B$. thuringiensis thuringiensis 4412 stand out for their ability of synthesizing Cry1Ba protein, which is highly toxic for $S$. frugiperda; and B. thuringiensis dendrolimus HD37, which synthesizes Cry1Aa protein, toxic for O. poecilus and $O$. oryzae. These strains can be indicated as agents in the microbiological control of the rice Integrated Pest Maganement (IPM), through their use in the formulation of new biopesticides, and using their cry genes for obtaining genetically modified rice plants resistant to these insects.

Table 3. Toxicity of Bacillus thuringiensis strains against the primary rice insect pests, Spodoptera frugiperda and Oryzophagus oryzae.

\begin{tabular}{lcc}
\hline \multirow{2}{*}{ Bacillus thuringiensis $(\boldsymbol{B t})$ strains } & \multicolumn{2}{c}{ \% Corrected Mortality (Mean \pm SE)* } \\
\cline { 2 - 3 } & O. oryzae & S. frugiperda \\
\hline Bt dendrolimus HD37 & $61.98 \pm 8.14 \mathrm{a}$ & $37.83 \pm 17.34 \mathrm{a}$ \\
Bt kurstaki HD1 & $56.94 \pm 10.41 \mathrm{a}$ & $4.9 \pm 4.90 \mathrm{a}$ \\
Bt kurstaki HD73 & $53.38 \pm 5.11 \mathrm{a}$ & $22.63 \pm 4.43 \mathrm{a}$ \\
Bt thuringiensis 4412 & $49.46 \pm 9.34 \mathrm{a}$ & $93.13 \pm 6.86 \mathrm{~b}$ \\
Bt entomocidus 60.5 & $49.82 \pm 7.30 \mathrm{a}$ & $85.63 \pm 5.39 \mathrm{~b}$ \\
Bt kurstaki NRD-12 & $64.48 \pm 12.70 \mathrm{a}$ & $8.96 \pm 3.66 \mathrm{a}$ \\
\hline *Mean and standard erro (SE); different letters following the means
\end{tabular}

\section{Insecticides and Bacillus thuringiensis strains interaction}

When the analyzed chemical insecticides were tested at the recommended doses they did not cause any bacterial growth inhibition in the evaluated $B$. thuringiensis strains. However, at a $10^{1}$ concentration, ten times higher than the recommended concentration, some insecticides presented inhibitory effect in the bacterial development, as shown in
Table 4.

The insecticide labdacyhalothrin was the only one that did not present any inhibitory effect on the analyzed $B$. thuringiensis strains in both concentrations, suggesting that it can be used simultaneously in insect pest control in rice field areas. The second insecticide with lower inhibitory activity was fipronil, which caused only a low inhibition to the $B$. 
thuringiensis kurstaki NRD-12 strain at the higher evaluated concentration. Furthermore, thiamethoxam also showed inhibitory action to the B. thuringiensis dendrolimus HD-37 strain at the higher dose.

The insecticide malathion inhibited the development of six out of seven evaluated $B$. thuringiensis strains at the higher concentration; for B. thuringiensis entomocidus 60.5 the strains had no effect.

B. thuringiensis kurstaki HD-1 strain obtained from a commercial product, which is already used in Rio Grande do Sul rice field areas (6), showed the higher inhibition when inoculated in presence of malathion at $7.500 \mathrm{~g}$ a.i./ha concentration.

The results obtained in this research corroborate with the study made by Batista Filho et al. (7), in which they analyzed the thiamethoxam insecticide effect over the bacterial growth of $B$. thuringiensis, also showing compatibility. Similar results were found by Almeida et al. (3), who showed that thiamethoxam was compatible with $B$. thuringiensis.

Silva et al. (36) evaluated B. thuringiensis kurstaki growth using discs impregnated with herbicides and suggested that the presence of inhibition was probably due to the selection of resistant colonies or due to the product's irregular distribution in the culture medium.

According to Alves et al. (5), the high toxicity of in vitro chemical insecticides does not suggest high field toxicity, but only indicates the possibility of damages of this nature. The authors state that the greatest difficulty for this study is the lack of test standardization, which most of the times does not allow an efficient comparison between the products.

These results demonstrated that the insecticides were compatible with the development of the Bacillus thuringiensis strains evaluated in this study, which can be used for the control of insect pests in rice field areas. It is recommended, though, that the chemical insecticides be used in the CTAR recommended doses (37). The results suggest that it is necessary to have special care in the application of insecticide malathion at the $7.500 \mathrm{~g}$ a.i./ha concentration, looking for the appropriate use of IPM in rice field areas, especially when using $B$. thuringiensis-based products.

Table 4. In vitro interaction data of Bacillus thuringiensis strains with chemical insecticides recommended by SOSBAI (37) to irrigated rice crops in south Brazil.

\begin{tabular}{|c|c|c|c|c|c|c|c|c|}
\hline \multirow{3}{*}{ Bacillus thuringiensis (Bt) strains } & \multicolumn{8}{|c|}{ Insecticides and evaluated doses (g a.i./ha) ${ }^{1}$} \\
\hline & \multicolumn{2}{|c|}{ Thiamethoxam } & \multicolumn{2}{|c|}{ Labdacyhalothrin } & \multicolumn{2}{|c|}{ Malathiom } & \multicolumn{2}{|c|}{ Fipronil } \\
\hline & 37.5 & 375 & 7.5 & 75 & 750 & 7500 & 37.5 & 375 \\
\hline Bt dendrolimus HD-37 & - & ++ & - & - & - & ++ & - & - \\
\hline Bt kurstaki HD-1 & - & - & - & - & - & + & - & - \\
\hline Bt kurstaki HD-73 & - & - & - & - & - & ++ & - & - \\
\hline Bt entomocidus 60.5 & - & - & - & - & - & - & - & - \\
\hline Bt thuringiensis 4412 & - & - & - & - & - & \pm & - & - \\
\hline Bt kurstaki NRD-12 & - & - & - & - & - & ++ & - & \pm \\
\hline Bt kurstaki HD1 (DIPEL ${ }^{\circledR}$ ) & - & - & - & - & - & +++ & - & - \\
\hline
\end{tabular}

\section{ACKNOWLEDGEMENTS}

To Dr. Fernando Hercos Valicente (EMBRAPA/CPACT), Dr. Bergmann Morais Ribeiro (UNB) and Dr. Marcelo Gravina de Moraes (UFRGS) for their contributions in the revision of this work, which corresponds to a part of the $\mathrm{PhD}$ thesis at the
Biology Graduation Program with CAPES support.

\section{REFERENCES}

1. Abbott, W.S. (1925). A method of computing the effectiveness of insecticide. J. Econ. Entomo. 18, 265-67. 
2. Ali, S.; Zafar, Y.; Xianyin, Z.; Ali, G.M.; Jumin, T. (2008). Transgenic crops: Current challenges and future perspectives. Afr. J. Biotechnol. 7(25), 4667-4676

3. Almeida, J.E.M.; Batista-Filho, A.; Lamas, C.; Leite, L.G.; Trama, M.; Sano, A.H. (2003). Avaliação da compatibilidade de defensivos agrícolas na conservação de microrganismos entomopatogênicos no manejo de pragas do cafeeiro. Arq. Inst. Biol. 70(1), 79-84.

4. Álvarez, A.; Virla, E.G.; Pera, L.M.; Baigorí, M.D. (2009). Characterization of native Bacillus thuringiensis strains and selection of an isolate active against Spodoptera frugiperda and Peridroma saucia. Biotechnol. Lett. 31, 1899-1903.

5. Alves, S.B. Controle microbiano de insetos. 2. ed. São Paulo: FEALQ, 1998. 326p.

6. Azambuja, I.H.V.; Vernetti-Junior, F.J.;Magalhães-Junior, A.M. (2005). Cultivo do Arroz Irrigado no Brasil. Sistemas de Produção, 3. Embrapa Clima Temperado. http://www.cpact.embrapa.br/publicacoes/catalogo/tipo/sistemas/arroz/c ap01

7. Batista-Filho, A.; Almeida, J.E.M.; Lamas, C. (2001). Effect of thiametoxam on entomopathogenic microrganisms. Neotrop. Entomol. 30(3), 437-447.

8. Bobrowski, V.L.; Pasquali, G.; Bodanese-Zanettini, M.H.; Fiuza, L.M. (2001). Detection of cryl genes in Bacillus thuringiensis isolates from South of Brazil and activity against Anticarsia gemmatalis (Lepidoptera: Noctuidae). Braz. J. Microbiol. 32(2), 105-109.

9. Bohorova, N.; Frutos, R.; Royer, M.; Estañol, P.; Pacheco, M.; Rascón, Q.; Mclean, S.; Hoisington, D. (2001). Novel synthetic Bacillus thuringiensis $c r y l B$ gene and the $c r y l B$-crylAb translational fusion confer resistance to southwestern corn borer, sugarcane borer and fall armyworm in transgenic tropical maize. Theor. Appl. Genet. 103, 817826.

10. Bradley, D.; Harkey, M.A.; Kim, M.K.; Biever, K.; Bauer, L.S. (1995). The insecticidal CryIB crystal protein of Bacillus thuringiensis ssp. thuringiensis has dual specificity to coleopteran and lepidopteran larvae. J. Inverteb.r Pathol. 65, 162-173.

11. Bravo, A.; Sarabia, S.; Lopez, L., Ontiveros, H.; Abarca, C.; Ortiz, A.; Ortiz, M.; Lina, L.; Villalobos, F.J.; Guadalupe, P.G.; Nunez-Valdez, M.A.; Soberón, M.; Quintero, R. (1998). Characterization of cry Genes in a Mexican Bacillus thuringiensis Strain Collection. Appl. Environ. Microbiol. 64 (12), 4965-4972.

12. Crickmore, N. (2006). Beyond the spore - past and future developments of Bacillus thuringiensis as a biopesticide. J. Appl. Microbiol. 101, 616619.

13. DeBarjac, H.; Lecadet, M.M. (1976). Dosage biochimique d'exotoxine thermostable de. Bacillus thuringiensis d'après l'inhibition d'ARNpolymerases bacteriennes. C. R. Acad. Sci. 282, 2119-2122.
14. Fatoretto, J.C.; Sena, J.A.D.; Barreto, M.R.; Lemos, M.V.F.; BoiçaJunior, A.L. (2007). Associação de bioensaios e caracterização molecular para seleção de novos isolados de Bacillus thuringiensis efetivos contra Spodoptera frugiperda (J.E. Smith) (Lepidoptera: Noctuidae). Neotrop. entomol. 36(5), 737-745.

15. Fiuza, L.M.; Berlitz, D.L. (2009). Produtos de Bacillus thuringiensis: registro e comercialização. Biotecnol. Cienc. Desenvolv. 38, 58-60.

16. Frankenhuyzen, K.V. (2009). Insecticidal activity of Bacillus thuringiensis crystal proteins. J. Invertebr. Pathol. 101, 1-16.

17. Fujimoto, H.; Itoh, K.; Yamamoto, M.; Kyozuka, J.; Shimamoto, K. (1993). Insect resistant rice generated by introduction of a modified deltaendotoxin gene of Bacillus thuringiensis. Biotechnol. 11, 11511155 .

18. Gitahy, P.M.; De-Souza, M.T.; Monnerat, R.G.; Arrigoni, E.B.; Baldani, J.I. (2007). A Brazilian Bacillus thuringiensis strain highly active to sugarcane borer Diatraea saccharalis (Lepidoptera: Crambidae). Braz. J. Microbiol. 38(3), 531-537.

19. Höfte, H.; Whiteley, H.R. (1989). Insecticidal crystal protein of Bacillus thuringiensis. Microbiol. Rev. 53(2), 242-255.

20. King, E. G.; Hartley, G.G. (1985). Diatraea saccharalis, In: Singh, P.; Moore. R.F. (eds.). Handbook of insect rearing. Elsevier, New York, p.265-270.

21. Laemmli, U.K. (1970). Cleavage of structural proteins during the assembly of the head of bacteriophage T4. Nature. 227, 680-685.

22. Lereclus, D.; Delécluse, E.; Lecadet, M.-M. (1993). Diversity of Bacillus thuringiensis toxins and genes. In: Entwistle, P.F.; Cory, J.S.; Bailey, M.J.; Higgs, S. (eds). Bacillus thuringiensis, an environmental biopesticide: theory and practice. John Wiley \& Sons, Chichester, U.K. p. 37-69.

23. Liang, H.; Liu, Y.; Zhu, J.; Guan, P.; Li, S.; Wang, S.; Zheng, A.; Liu, H.; Li, P. (2011). Characterization of cry2-type genes of Bacillus thuringiensis strains from soil-isolated of Sichuan basin, China. Braz. J. Microbiol. 42(1) 140-146.

24. López-Pazos, S.A.; Gómez, J.E..C.; Salamanca, J.A.C. (2009). Cry1B and Cry3A are active against Hypothenemus hampei Ferrari (Coleoptera: Scolytidae). J. Invertebr. Pathol. 101, 242-245.

25. Martins, E.S.; Monnerat, R.G.; Queiroz, P.R.; Dumas, V.F.; Braz, S.V.; Aguiar, R.W.D.; Gomes, A.C.M.M.; Sanchez, J.; Bravo, A.; Ribeiro, B.M. (2010). Midgut GPI-anchored proteins with alkaline phosphatase activity from the cotton boll weevil (Anthonomus grandis) are putative receptors for the Cry1B protein of Bacillus thuringiensis. Insect. Biochem. Mol. Biol. 40(2), 138-145.

26. Martins, E.S.; Praça, L.B.; Dumas, V.F.; Silva-Werneck, J.O.; Sone, E.H.; Waga, I.C.; Berry, C.; Monnerat, R.G. (2007). Characterization of Bacillus thuringiensis isolates toxic to cotton boll weevil (Anthonomus grandis). Bio.l Control. 40, 65-68. 
27. Martins, J.F.S.; Carbonari, J.J.; vendramim, J.D. (2004). Simulação do dano causado por larvas de Oryzophagus oryzae a cultivares de arroz irrigado. Cienc. Rural. 34, 653-659.

28. Oerke, E.C. (2006). Crop losses to pests. J. Agric. Sci. 144, 31-43.

29. Oliveira, J.V.; Freitas, T.F.S.; Fiuza, L.M.; Menezes, V.G.; Dotto, G. (2010). Manejo de insetos associados à cultura do arroz irrigado. Boletim Técnico 8, Cachoeirinha, RS.

30. Pinto, L.M.N.; Fiuza L.M. (2003). PCR and bioassays screening of Bacillus thuringiensis isolates from rice-fields of Rio Grande do Sul, specific to lepidopterans and coleopterans. Braz. J. Microbiol. 34, 305310 .

31. Pinto, L.M.N.; Fiuza L.M. (2008). Genes cry de Bacillus thuringiensis aplicados na engenharia genética de plantas, conferindo resistência a insetos-praga. Neotrop. Biol. Conserv. 3, 159-168.

32. Poitout, S.; Bues, R. (1974). Élevage des chenilles de vint huit espèces de lépidoptères Noctuidae et deux espèces d'Arctiidae sur milieu artificiel simple. Particularités de l'élevage selon les espèces. Ann. Zool. Ecol. Anim. 6, 431-441.

33. Polanczyk, R.A.; Silva, R.F.P.; Fiuza, L.M. (2000). Effectiveness of Bacillus thuringiensis strains against Spodoptera frugiperda (Lepidoptera: Noctuidae). Braz. J. Microbiol. 31(3), 164166.

34. Rosas-García, N.M.; Pereyra-Alférez, B.; Niño, K.A.; Galán-Wong, L.J.; Morales-Ramos, L.H. (2004). Novel toxicity of native and HD Bacillus thuringiensis strains to the sugarcane borer Diatraea saccharalis. BioControl. 49, 455-465.

35. Santos, K.B. dos; Neves, P.; Meneguim, A.M.; Santos, R.B.; Santos, W.J.; Boas, G.V.; Dumas, V.; Martins, E.; Praça, L.B.; Queiroz, P.; Berry, C.; Monnerat, R. (2009). Selection and characterization of the Bacillus thuringiensis strains toxic to Spodoptera eridania (Cramer), Spodoptera cosmioides (Walker) and Spodoptera frugiperda (Smith) (Lepidoptera: Noctuidae). BioControl. 50, 157-163.

36. Silva, E.R.L.; Alves, L.F.A.; Santos, J.; Potrich, M.; Sene, L. (2008). Técnicas para avaliação in vitro do efeito de herbicidas sobre Bacillus thuringiensis Berliner var. Kurstaki. Arq. Inst. Bio. 75(1), 59-67.

37. Sociedade Sul-Brasileira de Arroz Irrigado - SOSBAI. (2007). Recomendações técnicas de pesquisa para o sul do Brasil - Arroz irrigado. V Congresso Brasileiro de Arroz Irrigado e XXVII Reunião da Cultura do Arroz Irrigado, Pelotas, RS, p. 161.

38. Sociedade Sul-Brasileira de Arroz Irrigado - SOSBAI. (2010). ARROZ IRRIGADO: Recomendações Técnicas da Pesquisa para o Sul do Brasil. XXVIII Reunião técnica da cultura do arroz irrigado, Pelotas. http://www.sosbai.com.br/recomendacoes.php

39. Souza, A.M.L.; Ávila, C.J.; Parra, J.R.P. (2001). Consumo e Utilização de Alimento por Diatraea saccharalis (Fabr.) (Lepidoptera: Pyralidae), Heliothis virescens (Fabr.) e Spodoptera frugiperda (J.E. Smith) (Lepidoptera: Noctuidae) em Duas Temperaturas. Neotropical Entomology. 30(1), 11-17.

40. SPSS. (2002). SPSS 11.5 for windows. SPSS, Chicago, IL.

41. Valicente, F.H.; Picoli, E.A.T.; Vasconcelos, M.J.V.; Carneiro, N.P.; Carneiro, A.A.; Guimarães, C.T.; Lana, U.G. (2010). Molecular characterization and distribution of Bacillus thuringiensis cryl genes from Brazilian strains effective against the fall armyworm, Spodoptera frugiperda. Biol. Control. 53(3), 360-366.

42. Vieira, N.R.A.; Santos, A.B.; Sant'Ana, E.P. (1999). A cultura do arroz no Brasil. Embrapa-CNPAF, Santo Antônio de Goiás.

43. Walters, F.S.; English, L.H. (1995). Toxicity of Bacillus thuringiensis dendotoxins toward the potato aphid in an artificial diet bioassay. Entomol. Exp. Appl. 77, 211-216.

44. Wellman-Desbiens, L.; Côte, J.C. (2004). Screening of the Insecticidal Activity of Bacillus thuringiensis Strains Against Lygus hesperus (Hemiptera: Miridae) Nymphal Population. J. Econ. Entomol. 97(2), 251-258.

45. Wu, X.; Leonard, B.R.; Zhu, Y.C.; Abel, C.A.; Head, G.P.; Huang, F. (2009). Susceptibility of Cry1Ab-resistant and -susceptible sugarcane borer (Lepidoptera: Crambidae) to four Bacillus thuringiensis toxins. $J$. Invertebr. Pathol. 100, 29-34. 